\title{
Evidence for increased expression of the Amundsen Sea Low over the South Atlantic during the late Holocene
}

\author{
Zoë A. Thomas ${ }^{1,2,3}$, Richard T. Jones ${ }^{\text {a, }}$, Chris J. Fogwill ${ }^{1,2,5}$, Jackie Hatton ${ }^{4}$, Alan N. Williams ${ }^{2,3,6}$, Alan Hogg ${ }^{7}$, \\ Scott Mooney ${ }^{1}$, Philip Jones ${ }^{8}$, David Lister ${ }^{8}$, Paul Mayewski ${ }^{9}$, and Chris S. M. Turney ${ }^{1,2,3}$ \\ ${ }^{1}$ Palaeontology, Geobiology and Earth Archives Research Centre, School of Biological, Earth and Environmental Sciences, \\ University of New South Wales, Australia \\ ${ }^{2}$ Climate Change Research Centre, School of Biological, Earth and Environmental Sciences, \\ University of New South Wales, Australia \\ ${ }^{3}$ ARC Centre of Excellence in Australian Biodiversity and Heritage (CABAH), School of Biological, Earth and \\ Environmental Sciences, University of New South Wales, Sydney, Australia \\ ${ }^{4}$ Department of Geography, Exeter University, Devon, EX4 4RJ, UK \\ ${ }^{5}$ School of Geography, Geology and the Environment, Keele University, Staffordshire, ST5 5BG, UK \\ ${ }^{6}$ Extent Heritage Pty Ltd, 3/73 Union Street, Pyrmont, NSW 2009, Australia \\ ${ }^{7}$ Waikato Radiocarbon Dating Laboratory, University of Waikato, Private Bag 3105, Hamilton, New Zealand \\ ${ }^{8}$ Climatic Research Unit, School of Environmental Sciences, University of East Anglia, Norwich, UK \\ ${ }^{9}$ Climate Change Institute, University of Maine, Orono, ME, USA \\ a formerly at: Department of Geography, Exeter University, Devon, EX4 4RJ, UK \\ $\dagger$ deceased
}

Correspondence: Zoë A. Thomas (z.thomas@unsw.edu.au)

Received: 15 February 2018 - Discussion started: 1 March 2018

Accepted: 8 October 2018 - Published: 13 November 2018

\begin{abstract}
The Amundsen Sea Low (ASL) plays a major role in the climate and environment of Antarctica and the Southern Ocean, including surface air temperature and sea ice concentration changes. Unfortunately, a relative dearth of observational data across the Amundsen and Bellingshausen seas prior to the satellite era (post-1979) limits our understanding of the past behaviour and impact of the ASL. The limited proxy evidence for changes in the ASL are primarily restricted to the Antarctic where ice core evidence suggests a deepening of the atmospheric pressure system during the late Holocene. However, no data have previously been reported from the northern side of the ASL. Here we report a highresolution, multi-proxy study of a 5000-year-long peat record from the Falkland Islands, a location sensitive to contemporary ASL dynamics which modulates northerly and westerly airflow across the southwestern South Atlantic sector of the Southern Ocean. In combination with climate reanalysis, we find a marked period of wetter, colder conditions most likely the result of enhanced southerly airflow between 5000 and
\end{abstract}

2500 years ago, suggesting limited ASL influence over the region. After 2500 years ago, drier and warmer conditions were established, implying more westerly airflow and the increased projection of the ASL onto the South Atlantic. The possible role of the equatorial Pacific via atmospheric teleconnections in driving this change is discussed. Our results are in agreement with Antarctic ice core records and fjord sediments from the southern South American coast, and suggest that the Falkland Islands provide a valuable location for reconstructing high southern latitude atmospheric circulation changes on multi-decadal to millennial timescales.

\section{Introduction}

The leading mode of variability in atmospheric circulation across the southern mid-high latitudes is the Southern Annular Mode (SAM), manifested as the pressure difference between 65 and $40^{\circ} \mathrm{S}$ (Marshall, 2003; Thompson et al., 2011). 
The multi-decadal trend to a more positive SAM since the mid-20th century (Fogt et al., 2012; Hosking et al., 2013) is expressed by a strengthening and poleward shift of midlatitude westerly airflow and storm tracks over the Southern Ocean (Marshall, 2003; Thompson et al., 2011; Visbeck, 2009; Fig. 1), and has been linked to changes in climate, ocean ventilation, air-sea carbon flux, sea ice trends, and ice sheet dynamics on interannual to multi-decadal timescales (Le Quéré et al., 2007; Pritchard et al., 2012; Landschützer et al., 2015; J. M. Jones et al., 2016; Thomas et al., 2018). Whilst the SAM may dominate contemporary climate across the mid-latitudes, other climate modes and atmospheric patterns also play important roles both spatially and temporally. Arguably the most important in this regard is the Amundsen Sea Low (ASL), a quasi-stationary low-pressure system located in the Amundsen and Bellingshausen seas $\left(45-75^{\circ} \mathrm{S}\right.$, $\left.180-60^{\circ} \mathrm{W}\right)-$ a consequence of the Antarctic Peninsula and regional topography that dynamically influences atmospheric flow across this sector of the Southern Ocean (Fogt et al., 2012; Hosking et al., 2013; Turner et al., 2013). Proxy reconstructions of SAM and/or associated westerly winds have been generated for the Holocene (Sime et al., 2010; Dixon et al., 2012; Fletcher and Moreno, 2012; Moreno et al., 2012; Abram et al., 2014; Mayewski et al., 2017; Turney et al., $2017 \mathrm{~b}$ ), but there is a relative dearth of records regarding the past behaviour of the ASL (Mayewski et al., 2013).

Seasonally, the ASL migrates across the Bellingshausen Sea into the Ross Sea: during the austral summer, the pressure minimum extends east to the Antarctic Peninsula (reaching its lowest geopotential height off coastal West Antarctica in the Amundsen Sea), while in winter, the ASL migrates to the west into the eastern Ross Sea (Fogt et al., 2012). As a result, the ASL plays a dominant role in climate and environmental variability across the wider southern Pacific and southwestern South Atlantic sectors of the Southern Ocean (Kreutz et al., 2000; Turner et al., 2016). In particular, both the geopotential height and the location of the ASL affect regional synoptic conditions that extend into the interior of West Antarctica and southern South America (Ding et al., 2011; Schneider et al., 2012; Clem et al., 2017). Across the period from 1979 to 2008 (the satellite era) the ASL appears to have deepened, with associated changes in the strength and location of the mid-latitude jet as described by the zonally averaged SAM index (J. M. Jones et al., 2016). This deepening has been linked to stratospheric ozone depletion (J. M. Jones et al., 2016; Raphael et al., 2016; Clem et al., 2017) as well as reduced sea ice along the western Antarctic Peninsula and climate changes across a broader sector of the Southern Ocean (Turner et al., 2013; J. M. Jones et al., 2016; Turney et al., 2016b). Other possible drivers of ASL dynamics operating on a range of timescales are changes in the equatorial Pacific (Lachlan-Cope and Connolley, 2006; Ding et al., 2011; Abram et al., 2014; Turney et al., 2017a) and the Interdecadal Pacific Oscillation (IPO) (Meehl et al.,
2016), although these are not necessarily exclusive to one another.

The lack of long-term surface-based (in situ) observations in the Amundsen, Bellingshausen and Ross seas severely limits our understanding of the properties and impact of the ASL on multi-decadal to millennial timescales; this is an important consideration given uncertainties regarding the response of the ASL to future anthropogenic forcing (IPCC AR5, 2013). Fortunately, palaeoclimate proxy data from the region integrated with reanalysis data offer an opportunity to identify processes and mechanisms on timescales beyond those of satellite-era observations (since 1979). However, a major challenge with reconstructing changes in the ASL is disentangling the role of mid-latitude westerly airflow associated with SAM. The location of the palaeo-records and the proxies used are crucial in this regard. For instance, recent work from Siple Dome in the West Antarctic recognised increased delivery of sea salt sodium $\left(\mathrm{ssNa}^{+}\right)$interpreted as representing a deepening of the ASL, with a particularly marked trend since 2900 years ago (hereafter $2.9 \mathrm{ka}$ ) (Mayewski et al., 2013). Although Siple Dome provides an important southern "observation" point, information is needed on the northern side of the ASL to provide a more complete reconstruction of its location and/or depth during the Holocene, as well as a more thorough understanding of tropical Pacific-high latitude teleconnections. Here we report a new high-resolution record of local vegetation change and "exotic" macrofossils - the latter a proxy for westerly airflow - extending the record over the past $5 \mathrm{ka}$ and demonstrating a marked change in synoptic conditions around $2.5 \mathrm{ka}$. This provides important new insights into the long-term behaviour of the ASL and the role of the tropical Pacific.

\section{Study site}

The Falkland Islands lie at $52^{\circ} \mathrm{S}, 540 \mathrm{~km}$ east of the coast of South America and $1500 \mathrm{~km}$ west of subantarctic South Georgia (Fig. 1). The present climate of the Falkland Islands is highly influenced by the surrounding cool South Atlantic waters resulting in a cool temperate, maritime climate, with corresponding low seasonality. Weather station data from the east Falkland Islands (Mount Pleasant Airport) reveal a mean annual temperature of $5.5^{\circ} \mathrm{C}$, high mean monthly and annual wind speeds of ca. $8.5 \mathrm{~m} \mathrm{~s}^{-1}$ (with prevailing westerly winds), and relatively low annual precipitation of ca. $600 \mathrm{~mm}$, distributed uniformly throughout the year (Lister and Jones, 2014).

The Falkland Islands are dominated by extensive undulating lowlands, but several upland areas in excess of $500 \mathrm{~m}$ above sea level (a.s.l.) occur within the archipelago. The islands are not glaciated today and record only two periods of restricted glaciation in the Late Pleistocene (Clapperton, 1971, 1990; Clapperton and Sugden, 1976; Roberts, 1984). Blanket peat was established across large parts of 
the archipelago from $16.5 \mathrm{ka}$ (Wilson et al., 2002). The islands are situated within the main latitudinal belt of Southern Hemisphere westerly airflow (Barrow, 1978), and are therefore ideally placed to monitor changing Holocene wind strength across the South Atlantic. The need to understand the climate impacts is an urgent one; recent studies have suggested that with the projected increase in temperatures on the Falkland Islands, upland species are highly vulnerable to climate change (Upson et al., 2016).

To investigate past airflow, a $1.5 \mathrm{~m}$ sequence was taken with a D-section corer from an exposed Ericaceous-grass peatland on Canopus Hill $\left(51.691^{\circ} \mathrm{S}, 57.785^{\circ} \mathrm{W}\right.$, approximately $30 \mathrm{~m}$ a.s.1.), outside Port Stanley (35 km from Mount Pleasant Airport). The uniform dark-brown peat was contiguously sampled for pollen, charcoal and comprehensive radiocarbon dating. Work at this site has previously recognised the input of exotic pollen and charcoal derived from South America but was limited to the last $2.5 \mathrm{kyr}$ (Turney et al., 2016a).

\section{Methods}

\subsection{Pollen and charcoal analysis}

The pollen samples were prepared using standard palynological techniques (Faegri and Iverson, 1975). Volumetric samples were taken every $1 \mathrm{~cm}$ along the core, with $L y$ copodium spores added as a "spike". The samples were deflocculated with hot $10 \% \mathrm{NaOH}$ and then sieved through a $106 \mu \mathrm{m}$ mesh, before acetolysis, to remove extraneous organic matter. The samples were mounted in silicon oil and pollen types/palynomorphs were counted at $400 \times$ magnification until a minimum of 300 target grains were identified. Pollen/palynomorphs were identified using standard pollen keys (Barrow, 1978; Macphail and Cantrill, 2006) and the pollen type slide collection at the University of Exeter, UK. The pollen counts were expressed as percentages, with only total land pollen (TLP) contributing to the final pollen sum. The Lycopodium "spike" was also used to calculate total and individual pollen concentrations (grains $\mathrm{cm}^{-3}$ ) (Stockmarr, 1971), and these values were divided by the deposition time $\left(\mathrm{yr} \mathrm{cm}^{-1}\right)$ to calculate pollen accumulation rates (PAR; grains $\mathrm{cm}^{-2} \mathrm{yr}^{-1}$ ). Major pollen zone boundaries were determined using CONISS (stratigraphically constrained cluster analysis; Grimm, 1987) using the "rioja" package in R (Juggins, 2017). Past fire activity was investigated using counts of micro-charcoal fragments $(<106 \mu \mathrm{m})$ identified on the pollen slides (Whitlock and Larsen, 2001). Counts were undertaken at each level until a fixed total of 20 Lycopodium spores were counted and the total expressed as a concentration (fragments per $\mathrm{cm}^{3}$ ). The charcoal accumulation rate (CHAR) was calculated by dividing the total charcoal concentration by the deposition time estimated from the age-depth relationship.

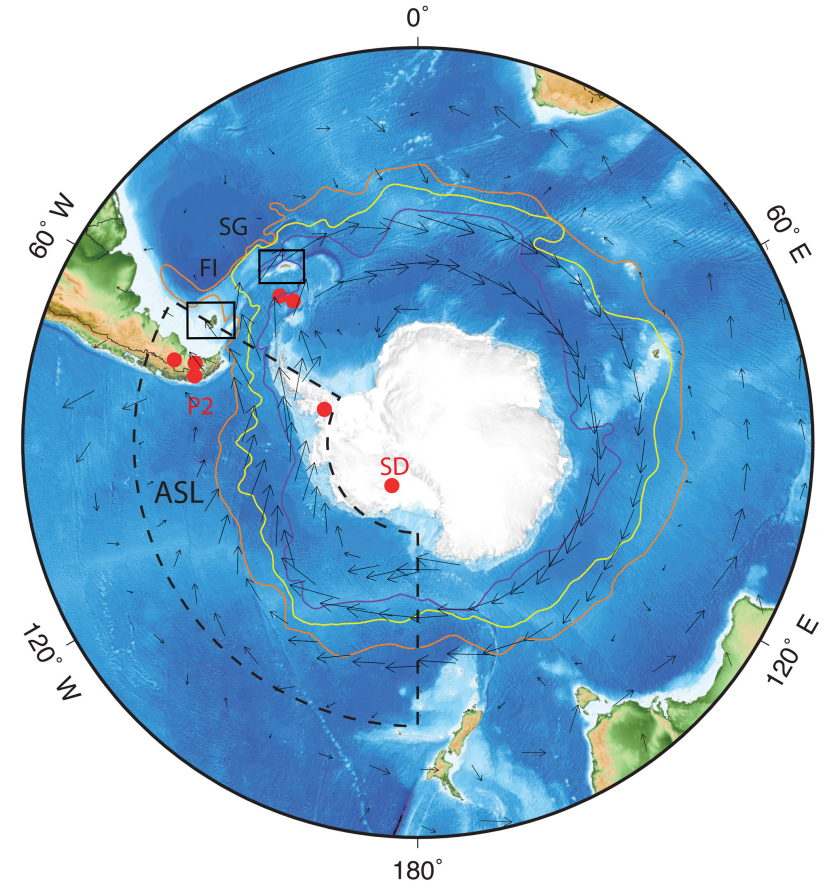

Figure 1. Location of the Falkland Islands (FI) and South Georgia (SG) in the South Atlantic (black boxes). Other key records from the region, including Siple Dome (SD) and Palm2 (P2) (red dots). The dashed line denotes the contemporary limits of the ASL domain defined across the 1979-2001 average (Fogt et al., 2012). The mean locations of the southern limb of the Antarctic Circumpolar Current (purple), the polar front (red) and the subantarctic front (green) are shown, following Orsi et al. (1995), based on analyses of hydrographic station data available up to 1990 . The grey arrows denote the $925 \mathrm{hPa}$ wind (vectors) trends since 1979 from ERA-Interim (Dee et al., 2011), depicting the location and increase in westerly winds over the satellite era (Turney et al., 2017a). Map made using Generic Mapping Tools (GMT) (Wessel et al., 2013).

\subsection{Radiocarbon and ${ }^{137} \mathrm{Cs}$ dating}

To derive a chronological framework for the Canopus Hill peat sequence, terrestrial plant macrofossils (fruits and leaves) were extracted. These macrofossils were given an acid-base-acid (ABA) pre-treatment and then combusted and graphitised in the University of Waikato AMS laboratory, with ${ }^{14} \mathrm{C} /{ }^{12} \mathrm{C}$ measurement by the University of California at Irvine (UCI) on a NEC compact (1.5SDH) AMS system. The pre-treated samples were converted to $\mathrm{CO}_{2}$ by combustion in sealed pre-baked quartz tubes, containing $\mathrm{Cu}$ and $\mathrm{Ag}$ wire. The $\mathrm{CO}_{2}$ was then converted to graphite using $\mathrm{H}_{2}$ and an $\mathrm{Fe}$ catalyst, and loaded into aluminium target holders for measurement at UCI. The ${ }^{14} \mathrm{C}$ measurements were supplemented by ${ }^{137} \mathrm{Cs}$ measurements near the top of the profile to detect the onset of nuclear tests in the mid20th century. The anthropogenic radionuclide ${ }^{137} \mathrm{Cs}$ (with a half-life of 30 years) is derived from atmospheric nuclear weapons testing and can provide an important "first appear- 
Table 1. Radiocarbon and modelled calibrated age ranges for the Canopus Hill peat sequences using the P_sequence and "outlier analysis" option in OxCal 4.2 (Bronk Ramsey, 2008; Bronk Ramsey and Lee, 2013). The SHCal13 (Hogg et al., 2013) and Bomb04SH (Hua and Barbetti, 2004) calibration curves were used. Note: calibrated ages are relative to before present (BP) i.e. CE 1950.

\begin{tabular}{|c|c|c|c|c|c|c|}
\hline \multirow[t]{2}{*}{ Depth $(\mathrm{cm})$} & \multirow[t]{2}{*}{$\begin{array}{l}\text { Wk lab } \\
\text { number }\end{array}$} & \multirow[t]{2}{*}{ Material } & \multirow[t]{2}{*}{$\begin{array}{l}\% \text { Modern/ } \\
{ }^{14} \mathrm{CBP} \pm 1 \sigma\end{array}$} & $\begin{array}{r}2 \sigma \text { cal age range } \\
(\text { years } \mathrm{BP})\end{array}$ & $\begin{array}{r}2 \sigma \text { cal age range } \\
(\text { years } \mathrm{BP})\end{array}$ & $\begin{array}{r}\text { Mean cal age } \\
(\text { years BP })\end{array}$ \\
\hline & & & & With two basal ages & \multicolumn{2}{|c|}{ Excluding two basal ages } \\
\hline $8-9$ & 34598 & Fruits and leaves & $117.0 \pm 0.4 \% \mathrm{M}$ & -4 to -43 & -4 to -44 & -21 \\
\hline 9 & & ${ }^{137} \mathrm{Cs}$ & & -6 to -42 & -6 to -42 & -19 \\
\hline $11-12$ & 32994 & Fruits and leaves & $107.8 \pm 0.4 \% \mathrm{M}$ & -2 to -14 & -1 to -14 & -8 \\
\hline $18-19$ & 37007 & Fruits and leaves & $107.3 \pm 0.3 \% \mathrm{M}$ & 0 to -13 & 26 to -15 & -3 \\
\hline $25-26$ & 35146 & Fruits and leaves & $95 \pm 25$ & 250 to -1 & 250 to -1 & 86 \\
\hline $35-36$ & 37008 & Fruits and leaves & $650 \pm 25$ & 650 to 550 & 650 to 550 & 600 \\
\hline $39-40$ & 33445 & Fruits and leaves & $760 \pm 25$ & 720 to 570 & $720-570$ & 660 \\
\hline $57-58$ & 32996 & Fruits and leaves & $1820 \pm 25$ & 1800 to 1600 & 1800 to 1600 & 1680 \\
\hline $70-71$ & 32350 & Fruits and leaves & $2240 \pm 25$ & 2320 to 2100 & 2310 to 2100 & 2220 \\
\hline $97-98$ & 32997 & Fruits and leaves & $2750 \pm 25$ & 2870 to 2760 & 2870 to 2760 & 2810 \\
\hline $107-108$ & 32998 & Fruits and leaves & $2910 \pm 26$ & 3140 to 2880 & 3140 to 2880 & 3000 \\
\hline $120-121$ & 41767 & Fruits and leaves & $3240 \pm 20$ & 3480 to 3360 & 3470 to 3360 & 3420 \\
\hline $141-142$ & 32351 & Fruits and leaves & $3960 \pm 32$ & 4430 to 4180 & 4510 to 4240 & 4350 \\
\hline $148-149$ & 41768 & Fruits and leaves & $4390 \pm 20$ & 4520 to 4300 & 5030 to 4850 & 4910 \\
\hline $153.5-154.5$ & 42144 & Fruits and leaves & $4040 \pm 21$ & 4520 to 4420 & & \\
\hline $156.5-157.5$ & 42145 & Fruits and leaves & $4080 \pm 22$ & 4570 to 4430 & & \\
\hline
\end{tabular}

ance" horizon of known age (1954-1955) i.e. an independent marker horizon to assist with age model validation (Hancock et al., 2011). ${ }^{137} \mathrm{Cs}$ analysis was undertaken following standard techniques with measurements made using an ORTEC high-resolution, low-background coaxial germanium detector. Specifically, we analysed contiguous peat samples for the first presence of ${ }^{137} \mathrm{Cs}$; detectable measurements were obtained down to $8.5-9.5 \mathrm{~cm}$.

\subsection{Age modelling}

The ${ }^{14} \mathrm{C}$ and ${ }^{137} \mathrm{Cs}$ ages were used to develop an age model using a P_sequence deposition model in OxCal 4.2 (Bronk Ramsey, 2008; Bronk Ramsey and Lee, 2013), with the "general outlier" analysis detection method (probability $=0.05$ ) (Bronk Ramsey, 2009). The ${ }^{14} \mathrm{C}$ ages were calibrated against the Southern Hemisphere calibration (SHCal13) data set (Hogg et al., 2013). The model was based on 1000 iterations, with the surface (depth zero) and year of sampling (2010) as the uppermost chronological control point. Using Bayes' theorem, the algorithms employed sample possible solutions with a probability that is the product of the prior and likelihood probabilities (Bronk Ramsey, 2008). Taking the deposition model and the actual age measurements into account, the posterior probability densities quantify the most likely age distributions; the outlier option was used to detect ages that fall outside the calibration model for each group, and if necessary, to down-weight their contribution to the final age estimates. The first presence of ${ }^{137} \mathrm{Cs}$ was assigned the prior $\mathrm{U}$ $(1952,2011)$ in the OxCal age model to capture the possible range of calendar years $(\mathrm{CE})$ for the onset of ${ }^{137} \mathrm{Cs}$ deposition in the sequence (Hancock et al., 2011). Modelled ages are reported here as thousands of calendar years before present (CE 1950) or ka (Table 1). We used the mean of the modelled age solutions to estimate the age of a fraction at each sample depth. The radiocarbon ages follow a stratigraphic order except for the two basal ages. We suspect these basal ages may comprise intruded younger root material; this is a scenario that is not unusual in relatively slowly accumulating sedimentary sequences (e.g. Brock et al., 2011). The sedimentation rate is internally more consistent when excluding these two basal ages; without them the sedimentation rate from the entire metre of sediment above does not change significantly (with a sedimentation rate for $141.5-156 \mathrm{~cm}$ of $38 \mathrm{yr} \mathrm{cm}^{-1}$ compared to an average of $27 \mathrm{yr} \mathrm{cm}^{-1}$ for the preceding metre of sediment), whereas including them abruptly increases the sedimentation rate over this depth range to $11.6 \mathrm{yr} \mathrm{cm}^{-1}$. The calibrated $2 \sigma$ age range for both the age model including and excluding these two basal ages are found in Table 1; the calibrated age ranges are almost identical for both age models until $142 \mathrm{~cm}$, where it then diverges. Importantly, our conclusions are not affected by the choice of age model.

\section{Results and discussion}

\subsection{Contemporary climate}

Regional climate dynamics were explored using the ERAInterim reanalysis (Dee et al., 2011), and the instrumental observations from Mount Pleasant Airport weather station on 

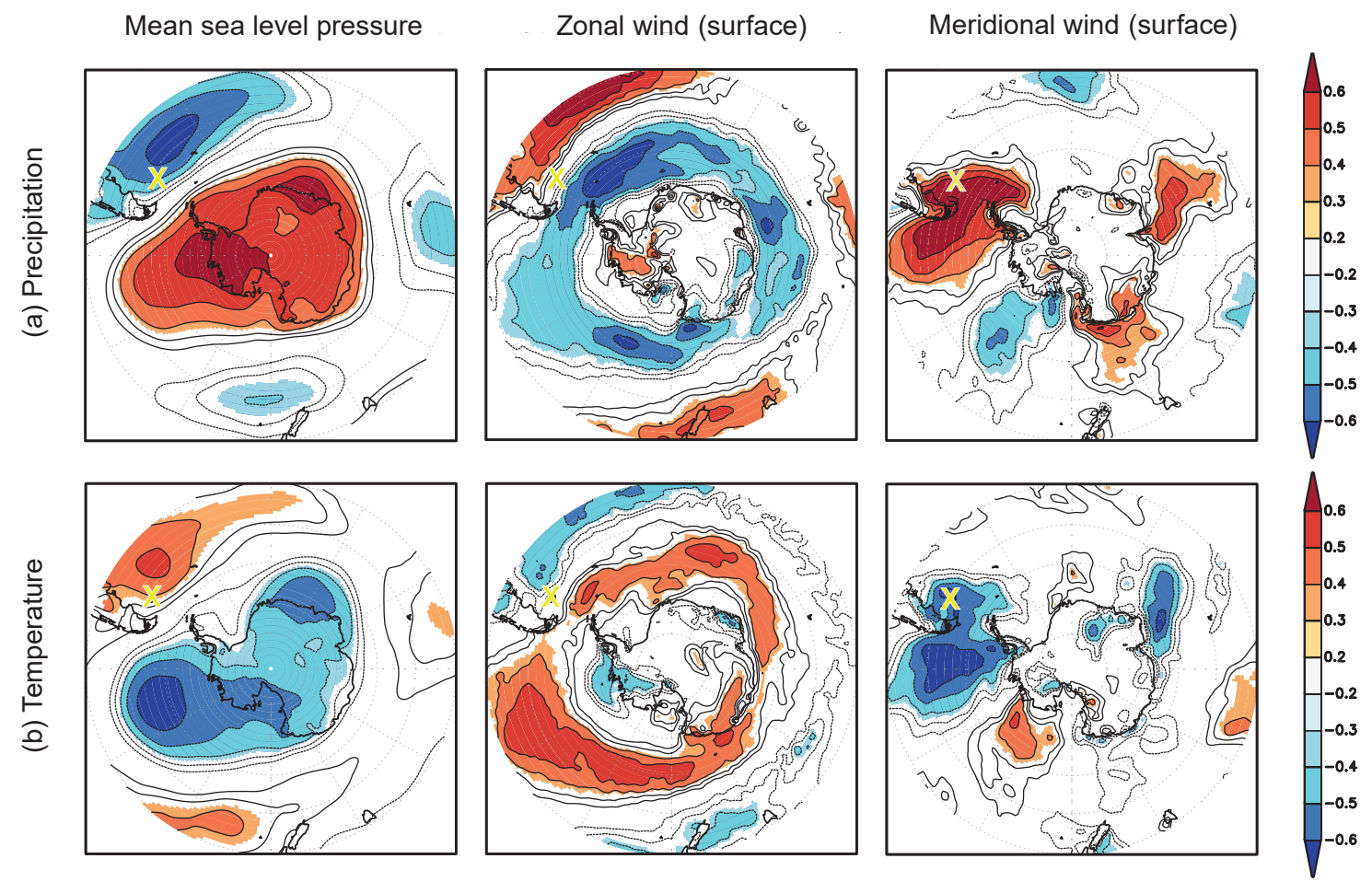

Figure 2. Spatial correlation of relationships between precipitation, temperature and synoptic conditions from Mount Pleasant Airport (October to March), Falkland Islands ("X"). The mean sea level pressure (MSLP), surface zonal wind and surface meridional wind correlated with October to March precipitation (a) and temperature (b) using ERA-79 Interim reanalysis (1979-2013; Dee et al., 2011). Significance $p_{\text {field }}<0.05$. Analyses were made with KNMI Climate Explorer (van Oldenborgh and Burgers, 2005).

the Falkland Islands (Lister and Jones, 2014; P. D. Jones et al., 2016). Given the seasonal nature of vegetation growth (including peat accumulation), spatial correlations using deseasonalised and detrended (to remove potential bias as a result of similar seasonal and long-term trends) spring-summer precipitation and temperature were investigated. These analyses show important links with atmospheric synoptic conditions (Fig. 2) including a clear link between precipitation and zonal and meridional circulation (Fig. 2c). Spatial correlations suggest limited ocean influence on these climate variables on the Falkland Islands. Crucially, wetter conditions are associated with a weakening of the ASL and the delivery of more southerly and easterly airflow across the South Atlantic (P. D. Jones et al., 2016). Conversely, more northerly airflow is associated with less precipitation over the Falklands. A similar picture emerges with variations in temperature (Fig. 2a and d) with a deeper (i.e. more intense low pressure) ASL associated with warmer temperatures over the Falkland Islands, and a weaker ASL with cooler conditions.

\subsection{Holocene climate and environmental change}

The Canopus Hill peat sequence reported here from the Falkland Islands represents one of the longest pollen records from the South Atlantic, with the only published early Holocene record from Barrow et al. (1978), which has limited age control and resolution. Our reconstruction appears to represent changing environmental conditions through the midto late-Holocene (Fig. 3). The pollen record is dominated by Poaceae and Empetrum, consistent with both previous studies and current vegetation on the islands (Barrow, 1978; Clark et al., 1998; Broughton and Mcadam, 2003; Turney et al., 2016a). However, in contrast to these previous studies, we observe a major shift in the representation of Cyperaceae and the total accumulation of pollen centred on $\sim 2.5 \mathrm{ka}$ (Fig. 4).

Similar changes to the above are also observed in the aeolian transportation of exotic pollen and charcoal derived from long-distance transport. These "exotic" pollen in the Canopus Hill sequence represent South American flora delivered to the site by westerly airflow. While only representing between $0.3 \%$ and $4.6 \%$ of the pollen sum, we recorded Nothofagus, Podocarpus, Ephedra fragilis and Anacardiumtype (arboreal) pollen grains. Nothofagus was the most frequently recorded exotic taxon in the samples, due to its high representation on Tierra del Fuego and the Islas de los Estados (upstream of the Falkland Islands), and high production of wind-dispersed pollen that can be carried over long distances (Moreno et al., 2009). In extreme situations, Nothofagus pollen has been recovered as far from South America as 


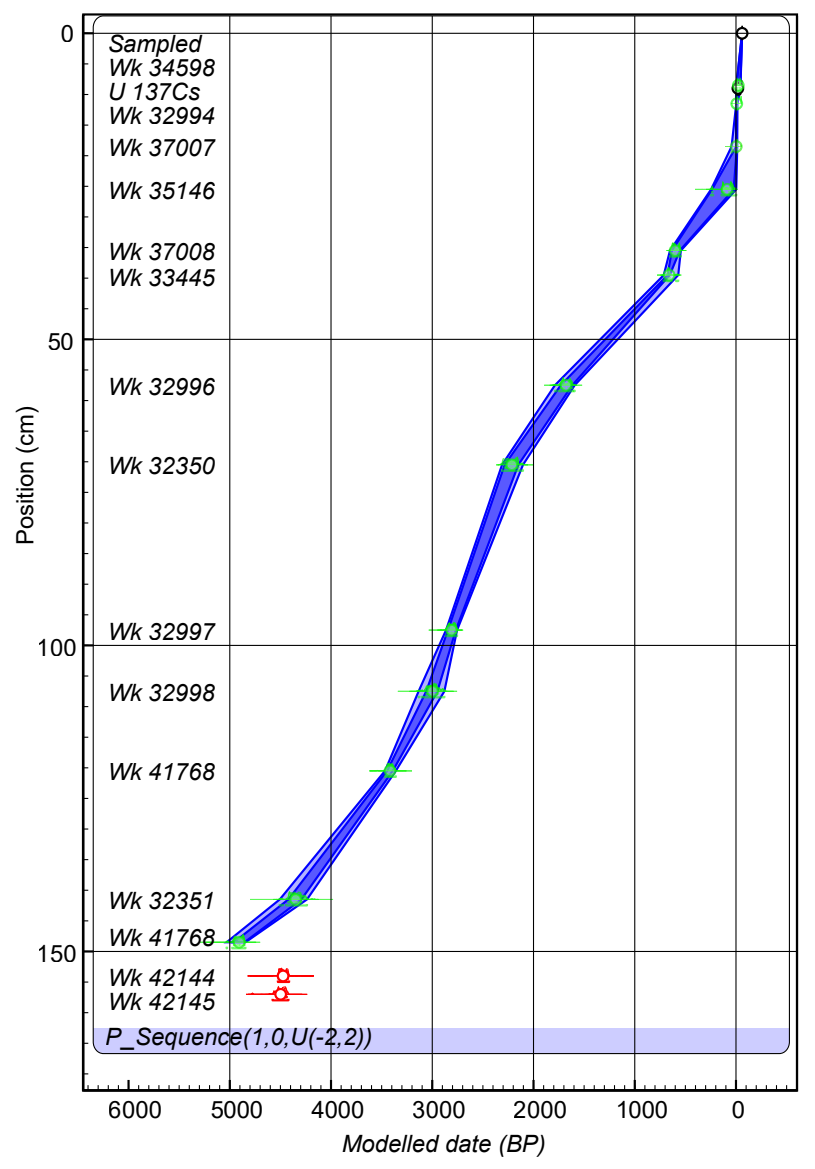

Figure 3. The age-depth relationship from Canopus Hill, with $1 \sigma$ and $2 \sigma$ age ranges (dark and light blue envelopes respectively) and probability distributions generated from the Bayesian age model. Red symbols indicate radiocarbon ages not incorporated into the age model. Radiocarbon ages were calibrated using SHCal13 atmospheric curve (Hogg et al., 2013) and "Post-bomb" atmospheric SH curve (Hua and Barbetti, 2004). Plot made with OxCal v4.3.2 (Bronk Ramsey, 2017).

Marion Island and Tristan da Cunha (Hafsten, 1960; Wace and Dickson, 1965; Mildenhall, 1976).

Differences in the exotic pollen assemblages can reflect either changes in the transport pathway (i.e. direction and wind strength) or regional vegetation change in the source area(s). Today, Nothofagus dominates lowland Patagonian vegetation and is found throughout Patagonian Late Glacial sequences. This taxa is thought to have been most widely established by $5 \mathrm{ka}$ (Kilian and Lamy, 2012; Iglesias et al., 2014), with a reasonably constant representation until stepped expansion at Lago Guanaco, almost directly west of the Falklands $\left(51.03^{\circ} \mathrm{S}, 72.83^{\circ} \mathrm{W}, 185 \mathrm{~m}\right.$ a.s.1.), centred on $570 \mathrm{cal}$ yr (Moreno et al., 2009; Villa-Martínez et al., 2012). Fire activity and the presence of exotic weeds introduced by European settlers is thought to have resulted in the rapid decline of Nothofagus at the end of the 19th century (Moreno et al.,
2009). The fact that Nothofagus is consistently represented throughout the Canopus Hill record indicates pervasive westerly winds throughout the mid- to late-Holocene, but does not have sufficiently high concentrations to robustly identify long-term changes.

Recent syntheses of charcoal stratigraphies across Patagonia have detected regional trends in biomass burning during the Holocene with a moderate increase occurring over the last 3000 years (Huber et al., 2004; Whitlock et al., 2007; Power et al., 2008). Highly variable counts of charcoal were obtained through the Canopus Hill sequence; however, more than $99 \%$ of charcoal fragments were less than $50 \mu \mathrm{m}$ in size, with negligible amounts identified in the 50-106 $\mu \mathrm{m}$ and $>106 \mu \mathrm{m}$ fractions (Fig. 4). As charcoal of this size can be transported long distances (Clark, 1988) it is likely that this influx of charcoal predominantly represent South American sources and westerly (and southwesterly) airflow, and that there was little or no fire in the local environment throughout the mid- to late-Holocene. The presence of fire in the Patagonian landscape during the late Holocene thus provides a ready source of exotic material for aerial transport to the Falkland Islands delivered via westerly airflow. The aeolian delivery of the charcoal to the Falkland Islands is supported by a correspondence between the Canopus Hill and the Lago Guanaco, southwestern Patagonian (Moreno et al., 2009), charcoal records. There is also a weak correlation between charcoal and Nothofagus, particularly in the younger half of the record, probably reflecting the similar transport modes.

Centennial-scale variability in the Canopus Hill charcoal record over the last $2.5 \mathrm{kyr}$ has previously been identified, which is apparently coherent with radiocarbon production rates (Turney et al., 2016a), suggesting that solar variability has a modulating influence on Southern Hemisphere westerly airflow. Similar cyclical variations in western Antarctic Peninsula glacier discharge as observed from the $\delta^{18} \mathrm{O}_{\text {diatom }}$ record from Site 1099 in the Palmer Deep, has also been detailed (Pike et al., 2013) which shows an underlying decrease towards lower values, reported from $\sim 2.5$ kyr. Specifically, this increased glacial ice discharge is considered to have been driven by atmospheric warming (as a result of peak local summer insolation; Fig. 5), supporting the findings from Canopus Hill.

\subsection{Holocene changes in the Amundsen Sea Low (ASL)}

Our results support the notion of pervasive westerly winds throughout the mid- to late-Holocene, as shown by the consistent representation of Nothofagus pollen, as well as the pollen of other rare exotic taxa including Podocarp, Ephedra fragilis and Anacardium-type found throughout the Canopus Hill peat sequence. Whilst the presence of Nothofagus implies that westerly airflow has been maintained across the South Atlantic, the relatively high expression of Cyperaceae between 5 and $\sim 2.5 \mathrm{ka}$ (Fig. 5) suggests enhanced delivery of cooler and moister air to the Falklands. Our analy- 


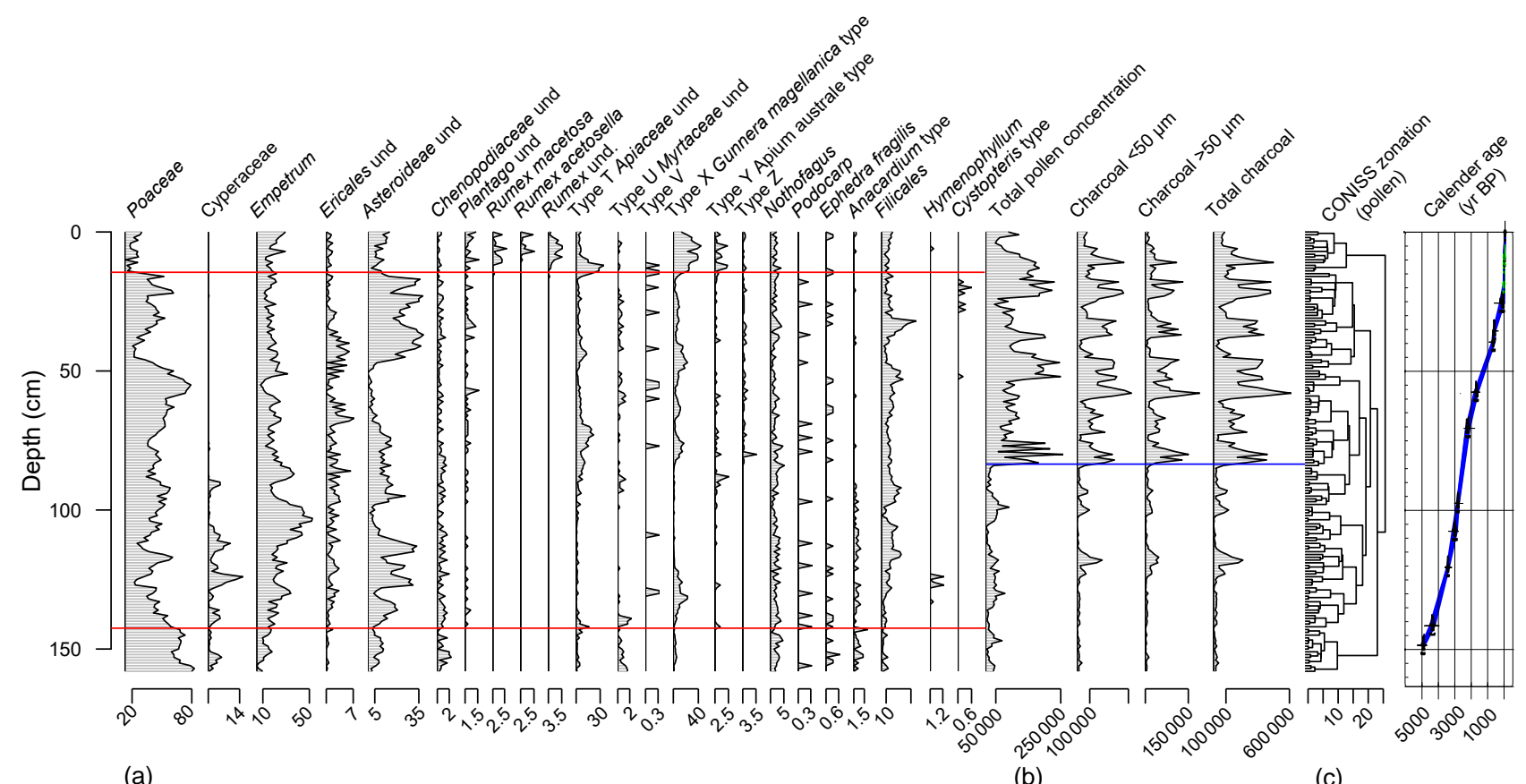

Figure 4. Summary pollen diagram from Canopus Hill, Port Stanley, describing palynomorphs as percentages of the total land pollen plotted against depth (a). The total pollen, charcoal of different size fractions and total charcoal expressed as a concentration (number $\left.\mathrm{cm}^{-3}\right)(\mathbf{b})$. Parallel lines denote major pollen (red) and charcoal/pollen concentration (blue) zone boundaries were determined using CONISS (Grimm, 1987). Age-depth relationship (c).

ses exploring contemporary drivers of synoptic conditions imply these conditions could have been brought about by more southerly airflow across the South Atlantic (Fig. 2), synoptic conditions inconsistent with today's expression of the ASL. The marked decline in Cyperaceae and the increase in charcoal at $\sim 2.5 \mathrm{ka}$ indicates a shift to drier and potentially warmer conditions, most probably a result of reduced southerly airflow and the northward movement and/or expansion of the ASL. The inferred increase in primary productivity and pollen accumulation on the islands supports this interpretation (Turney et al., 2016b).

These results complement other studies from the broader South Atlantic region (Fig. 5). Ice core-derived proxies from Siple Dome, located in a key region for understanding ASL dynamics, imply distinct changes in atmospheric circulation. Here, $\mathrm{ssNa}^{+}$provides a measure of sea-salt species, the transport of which is significantly influenced by the ASL (Kreutz et al., 2000), with higher values associated with a deeper ASL. The long-term increase of $\mathrm{ssNa}^{+}$over the mid- to lateHolocene thus implies a deepening of the ASL (Mayewski et al., 2013) consistent with our data. The slight difference in the timing between these records may be a consequence of chronological uncertainties or a lag in the projection of the ASL onto the South Atlantic (possibly reflecting an eastward migration/extension of the ASL to where it is more commonly located today). Further north, the marine sequence from the Palm2 within the Skyring fjord system west of the Andean crest of South America shows strong fluctuations of biogenic carbonate accumulation rates in superficial fjord waters (Lamy et al., 2010). This record represents marine carbonate production and its subsequent accumulation on the seabed in response to salinity changes in the upper water column of the fjord; prevailing westerly winds keep the low-salinity waters inside the fjord - therefore, lower salinity anomalies suggest stronger westerly winds. Intriguingly, the Palm2 record shows a pronounced sustained decrease in salinity anomalies from $\sim 2 / 2.5 \mathrm{ka}$ (Fig. 5), interpreted to be the result of a strengthening of mid-latitude westerly winds and a possible influence of the ASL, consistent with our reconstruction. The differences in the timing within the records that we compare may be an artefact of the uncertainties in the individual age models, or represent real dynamic changes operating on multi-decadal to centennial timescales. The changes at Palm2 do appear to be more abrupt than those observed at Siple Dome, but we do not interpret this as a regime shift (Thomas, 2016). The last age control point for the Palm2 record is from a marine shell at the start of the inflection, dating to $2570 \pm 30{ }^{14} \mathrm{CBP}$, calibrated to $2410 \mathrm{cal}$ yr BP (no $2 \sigma$ age range given), suggesting the age uncertainties between the changes observed in the Canopus Hill record and the Palm2 record may possibly overlap.

Taken together the above results imply that there was a long-term change in the behaviour of the ASL with the 


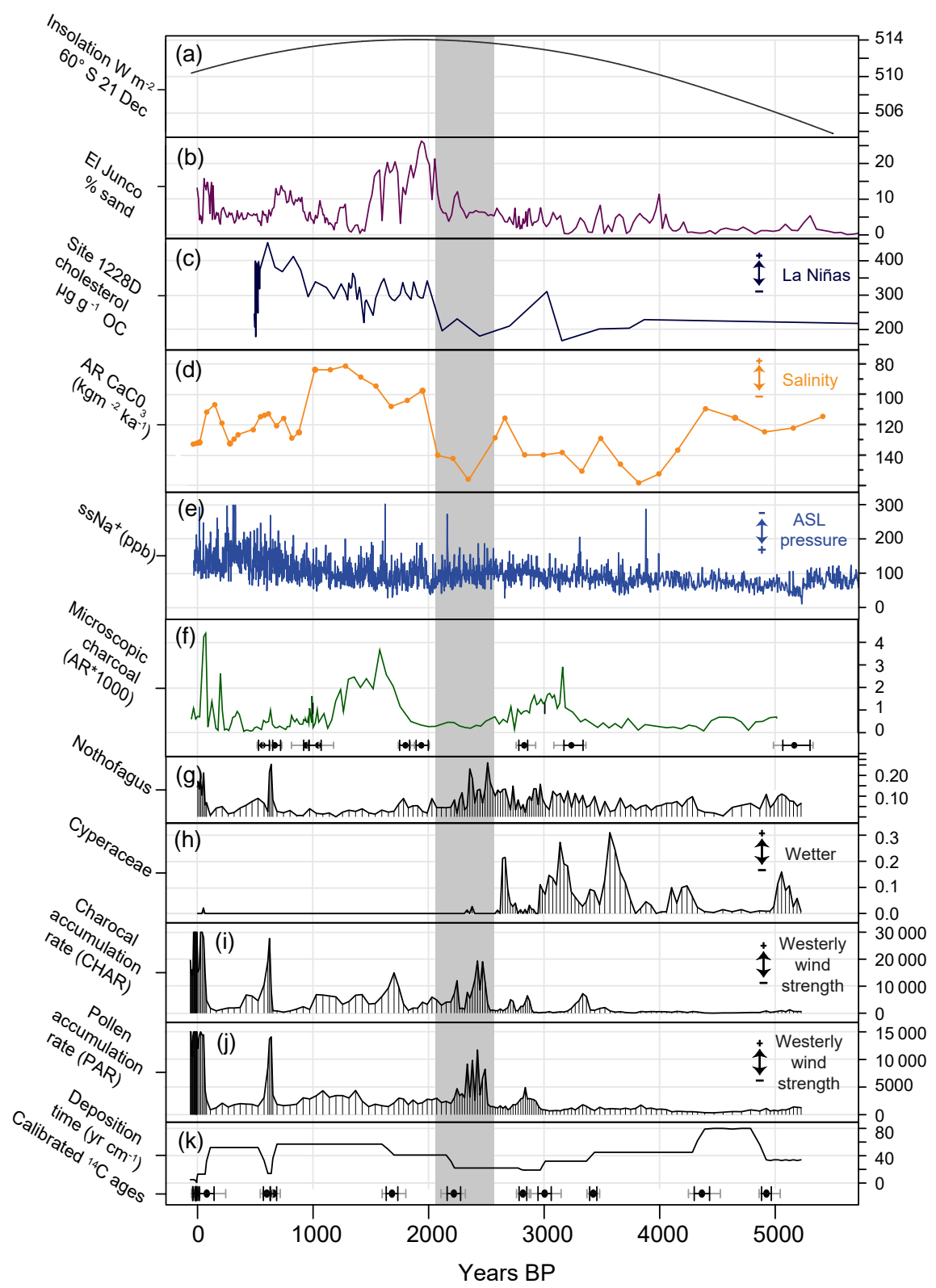

Figure 5. Key data from the Canopus Hill sequence (Falkland Islands) and other South Atlantic records. From bottom to top: deposition time; total pollen accumulation rate (PAR); total charcoal accumulation rate (CHAR); Cyperaceae and Nothofagus re-expressed as accumulation rates; microscopic charcoal from Lago Guanaco (Moreno et al., 2009); ssNa ${ }^{+}$from Siple Dome (Mayewski et al., 2013); salinity anomalies from Palm2 (Lamy et al., 2010); cholestrol abundance, ODP Site 1228, Peru margin (Makou et al., 2010); percentage of sand, El Junco Crater Lake, Galápogos (Conroy et al., 2008); and summer (21 December) insolation $\mathrm{W} \mathrm{m}^{-2}$ ) at $60^{\circ} \mathrm{S}$ (Laskar et al., 2004). Calibrated radiocarbon ages and $1 \sigma$ (black) and $2 \sigma$ (grey) age ranges for Canopus Hill and Lago Guanaco are plotted at the base of the respective panel. Note that PAR and CHAR have both been truncated at the modern end due to the high accumulation rate. The grey boxed area marks the transition period during which the ASL strengthened over the South Atlantic.

establishment of contemporary synoptic conditions around $2.5 \mathrm{ka}$. The reason for a change at $\sim 2.5 \mathrm{ka}$ is not immediately apparent but one possibility is the tropical Pacific. Today, equatorial Pacific ocean-atmospheric linkages are known to modulate the ASL with associated impacts across the broader region including climate, sea ice and ice sheet dynamics (Lachlan-Cope and Connolley, 2006; Ding et al., 2011; Abram et al., 2014; Turney et al., 2017a). Reconstructions of sea surface temperatures and precipitation suggest the establishment of more pervasive El Niño-Southern Oscillation (ENSO) activity from 3 to $2.5 \mathrm{ka}$ (Rein et al., 2005; Makou et al., 2010; Carre et al., 2014), which may have been 
projected onto the southeast Pacific sector of the Southern Ocean (Abram et al., 2014). The ENSO circulation pattern is teleconnected to Southern Ocean and Antarctic climate, in particular the Amundsen Sea low-pressure region, possibly via movements of the South Pacific Convergence Zone (Russell and McGregor, 2010). Contemporary La Niña events are accompanied by a northerly shift in the South Pacific Convergence Zone and the production of cyclones in the region of the Amundsen Sea low, enhancing warm northerly airflow over Patagonia, the western Antarctic Peninsula and the Falkland Islands. In addition, Fogt et al. (2011) found that when a La Niña event occurs during a positive phase of the SAM, the ASL deepens, suggesting that the SAM and the ASL may modulate one another. Whilst a shift to more negative IPO has been linked to a deepening of the ASL (Meehl et al., 2016), the long-term changes in this climate mode are currently uncertain. Given the projected increase in extreme ENSO events under future anthropogenic forcing (Cai et al., 2015) further work is needed to determine the mechanisms, timing and impacts of these low to high latitude teleconnections through the Holocene.

\section{Conclusion}

The Amundsen Sea Low (ASL) has been recognised as an important driver of Southern Ocean climate and environmental changes during the late-20th century. However, there are unfortunately limited observational and proxy data sets capturing the long-term behaviour and impact of the ASL. Here we report a comprehensively dated peat record from Canopus Hill (Falkland Islands) in the southwestern South Atlantic Ocean, a region highly sensitive to the ASL. Our multi-proxy study including local vegetation change and exotic pollen and charcoal (wind-blown macrofossils originating from South America) allows us to reconstruct climate changes over the last 5000 years. We observe a marked shift from pervasive wet and cool to drier and warmer conditions around $2.5 \mathrm{ka}$. ERA-Interim reanalysis suggests this change was a consequence of the establishment of contemporary westerly airflow associated with the ASL projecting onto the South Atlantic. The timing of this change is consistent with increased surface warming and expression of the El Niño-Southern Oscillation (ENSO) in the region, suggesting a strengthening of equatorial-high latitude atmospheric teleconnections. Our study demonstrates the value of the Falkland Islands for reconstructing atmospheric circulation changes across the southwestern South Atlantic on multidecadal to millennial timescales.

Data availability. The datasets generated and/or analysed during the current study are available from the corresponding author on request.
Author contributions. ZAT, RTJ, CJF, JH, ANW, AH, SM and CSMT were involved in the collection and analysis of the data. All authors contributed to the development of ideas and writing the paper.

Competing interests. The authors declare that they have no conflict of interest.

Acknowledgements. We would like to acknowledge the incredible debt we owe to our close friend and colleague Richard T. Jones without whom this work would not have been possible. We miss you Richard. This project was supported by the Australian Research Council (grant no. FL100100195 and DP130104156). We thank the Falkland Islands Government for permission to undertake sampling on the island (permit number R07/2011) and Darren Christie for assisting with the fieldwork. We thank two anonymous reviewers for their constructive comments on an earlier version of this manuscript.

Edited by: Dominik Fleitmann

Reviewed by: two anonymous referees

\section{References}

Abram, N. J., Mulvaney, R., Vimeux, F., Phipps, S. J., Turner, J., and England, M. H.: Evolution of the Southern Annular Mode during the past millennium, Nat. Clim. Change, 4, 1-6, https://doi.org/10.1038/NCLIMATE2235, 2014.

Barrow, C.: Postglacial pollen diagrams from south Georgia (subAntarctic) and West Falkland island (South Atlantic), J. Biogeogr., 5, 251-274, https://doi.org/10.2307/3038040, 1978.

Brock, F., Lee, S., Housley, R. A., and Bronk Ramsey, C.: Variation in the radiocarbon age of different fractions of peat: A case study from Ahrenshöft, northern Germany, Quat. Geochronol., 6, 550555, https://doi.org/10.1016/j.quageo.2011.08.003, 2011.

Bronk Ramsey, C.: Deposition models for chronological records, Quaternary Sci. Rev., 27, 42-60, https://doi.org/10.1016/j.quascirev.2007.01.019, 2008.

Bronk Ramsey, C.: Dealing with outliers and offsets in radiocarbon dating, Radiocarbon, 51, 1023-1045, 2009.

Bronk Ramsey, C.: OxCal Program Version 4.3, 2017.

Bronk Ramsey, C. and Lee, S.: Recent and Planned Developments of the Program OxCal, Radiocarbon, 55, 720-730, https://doi.org/10.2458/azu_js_rc.55.16215, 2013.

Broughton, D. A. and Mcadam, J. H.: The current status and distribution of the Falkland Islands pteridophyte flora, Fern Gaz., 17, 21-38, 2003.

Cai, W., Santoso, A., Wang, G., Yeh, S., An, S., Cobb, K. M., Collins, M., Guilyardi, E., Jin, F., Kug, J., Lengaigne, M., and Mcphaden, M. J.: ENSO and greenhouse warming, Nat. Clim. Change, 5, 849-859, https://doi.org/10.1038/nclimate2743, 2015.

Carre, M., Sachs, J. P., Purca, S., Schauer, A. J., Braconnot, P., Angeles Falcon, R., Julien, M., and Lavallee, D.: Holocene history of ENSO variance and asymmetry in the eastern tropical Pacific, Science, 345, 1045-1048, 2014. 
Clark, J. S.: Particle Motion and the Theory of Charcoal Analysis: Source Area, Transport, Deposition, and Sampling, Quaternary Res., 30, 67-80, 1988.

Clark, R., Huber, U. M., and Wilson, P.: Late Pleistocene sediments and environmental change at Plaza Creek, Falkland Islands, South Atlantic, J. Quaternary Sci., 13, 95-105, https://doi.org/10.1002/(SICI)10991417(199803/04)13:2<95::AID-JQS351>3.0.CO;2-G, 1998.

Clem, K. R., Renwick, J. A., and McGregor, J.: Large-Scale Forcing of the Amundsen Sea Low and Its Influence on Sea Ice and West Antarctic Temperature, J. Climate, 30, 8405-8424, https://doi.org/10.1175/JCLI-D-16-0891.1, 2017.

Conroy, J. L., Overpeck, J. T., Cole, J. E., Shanahan, T. M., and Steinitz-Kannan, M.: Holocene changes in eastern tropical Pacific climate inferred from a Galápagos lake sediment record, Quaternary Sci. Rev., 27, 1166-1180, https://doi.org/10.1016/j.quascirev.2008.02.015, 2008.

Dee, D. P., Uppala, S. M., Simmons, A. J., Berrisford, P., Poli, P., Kobayashi, S., Andrae, U., Balmaseda, M. A., Balsamo, G., Bauer, P., Bechtold, P., Beljaars, A. C. M., van de Berg, L., Bidlot, J., Bormann, N., Delsol, C., Dragani, R., Fuentes, M., Geer, A. J., Haimberger, L., Healy, S. B., Hersbach, H., Holm, E. V., Isaksen, L., Kallberg, P., Kohler, M., Matricardi, M., Mcnally, A. P., Monge-Sanz, B. M., Morcrette, J. J., Park, B. K., Peubey, C., de Rosnay, P., Tavolato, C., Thepaut, J. N., and Vitart, F.: The ERA-Interim reanalysis: Configuration and performance of the data assimilation system, Q. J. Roy. Meteor. Soc., 137, 553-597, https://doi.org/10.1002/qj.828, 2011.

Ding, Q., Steig, E. J., Battisti, D. S., and Küttel, M.: Winter warming in West Antarctica caused by central tropical Pacific warming, Nat. Geosci., 4, 398-403, https://doi.org/10.1038/ngeo1129, 2011.

Dixon, D. A., Mayewski, P. A., Goodwin, I. D., Marshall, G. J., Freeman, R., Maasch, A. and Sneed, S. B.: An ice-core proxy for northerly air mass incursions into West Antarctica, Int. J. Climatol., 32, 1455-1465, https://doi.org/10.1002/joc.2371, 2012.

Faegri, K. and Iverson, J.: Textbook of pollen analysis, Blackwell, Oxford, UK, 1975.

Fletcher, M.-S. and Moreno, P. I.: Have the Southern Westerlies changed in a zonally symmetric manner over the last 14000 years? A hemisphere-wide take on a controversial problem, Quatern. Int., 253, 32-46, https://doi.org/10.1016/j.quaint.2011.04.042, 2012.

Fogt, R. L., Wovrosh, A. J., Langen, R. A., and Simmonds, I.: The characteristic variability and connection to the underlying synoptic activity of the AmundsenBellingshausen Seas Low, J. Geophys. Res.-Atmos., 117, 1-22, https://doi.org/10.1029/2011JD017337, 2012.

Grimm, E. C.: CONISS: A Fortran 77 Program for stratigraphically constrained cluster analysis by the method of incrementatl sum of squares, Comput. Geosci., 13, 13-35, 1987.

Hafsten, U.: The Quaternary history of vegetation in the South Atlantic Islands, Philos. T. R. Soc. B, 152, 516-529, https://doi.org/10.1098/rspb.1960.0059, 1960.

Hancock, G. J., Leslie, C., Everett, S. E., Tims, S. G., Brunskill, G. J., and Haese, R.: Plutonium as a chronomarker in Australian and New Zealand sediments: A comparison with ${ }^{137} \mathrm{Cs}$, J. Environ. Radioactiv., 102, 919-929, https://doi.org/10.1016/j.jenvrad.2009.09.008, 2011.
Hogg, A. G., Hua, Q., Blackwell, P. G., Niu, M., Buck, C. E., Guilderson, T. P., Heaton, T. J., Palmer, J. G., Reimer, P. J., Reimer, R. W., Turney, C. S. M., and Zimmerman, S. R. H.: SHCAL13 Southern Hemisphere calibration, 0-50 000 years cal BP, Radiocarbon, 55, 1889-1903, 2013.

Hosking, J. S., Orr, A., Marshall, G. J., Turner, J., and Phillips, T.: The influence of the amundsen-bellingshausen seas low on the climate of West Antarctica and its representation in coupled climate model simulations, J. Climate, 26, 6633-6648, https://doi.org/10.1175/JCLI-D-12-00813.1, 2013.

Hua, Q. and Barbetti, M.: Review of tropospheric bomb ${ }^{14} \mathrm{C}$ data for carbon cycle modeling and age calibration purposes, Radiocarbon, 46, 1273-1298, 2004.

Huber, U. M., Markgraf, V., and Schäbitz, F.: Geographical and temporal trends in Late Quaternary fire histories of FuegoPatagonia, South America, Quaternary Sci. Rev., 23, 1079-1097, 2004.

Iglesias, V., Whitlock, C., Markgraf, V., and Bianchi, M. M.: Postglacial history of the Patagonian forest/steppe ecotone (41-43 S), Quaternary Sci. Rev., 94, 120-135, 2014.

IPCC AR5: Climate Change 2013: The Physical Science Basis. Contribution of Working Group I to the Fifth Assessment Report of the Intergovernmental Panel on Climate Change, edited by: Stocker, T. F., Qin, D., Plattner, G.-K., Tignor, M., Allen, S. K., Boschung, J., Nauels, A., Xia, Y., Bex, V., and Midgley, P. M.: Cambridge University Press, Cambridge, UK and New York NY, USA, 2013.

Jones, J. M., Gille, S. T., Goosse, H., Abram, N. J., Canziani, P. O., Charman, D. J., Clem, K. R., Crosta, X., de Lavergne, C., Eisenman, I., England, M. H., Fogt, R. L., Frankcombe, L. M., Marshall, G. J., Masson-Delmotte, V., Morrison, A. K., Orsi, A. J., Raphael, M. N., Renwick, J. A., Schneider, D. P., Simpkins, G. R., Steig, E. J., Stenni, B., Swingedouw, D., and Vance, T. R.: Assessing recent trends in high-latitude Southern Hemisphere surface climate, Nat. Clim. Change, 6, 917-926, https://doi.org/10.1038/nclimate3103, 2016.

Jones, P. D., Harpham, C., and Lister, D.: Long-term trends in gale days and storminess for the Falkland Islands, Int. J. Climatol., 36, 1413-1427, https://doi.org/10.1002/joc.4434, 2016.

Juggins, S.: Rioja: Analysis of Quaternary Science Data, R package, 2017.

Kilian, R. and Lamy, F.: A review of Glacial and Holocene paleoclimate records from southernmost Patagonia (49-55 S), Quaternary Sci. Rev., 53, 1-23, 2012.

Kreutz, K. J., Mayewski, P. A., Pittalwala, I., Meeker, L. D., Twickler, M. S., and Whitlow, S. I.: Sea level pressure variability in the Amundsen Sea region inferred from a West Antarctic glaciochemical record, J. Geophys. Res., 105, 4047-4059, 2000.

Lachlan-Cope, T. and Connolley, W.: Teleconnections between the tropical Pacific and the Amundsen- Bellinghausens Sea: Role of the El Niño/Southern Oscillation, J. Geophys. Res., 111, D23101, https://doi.org/10.1029/2005JD006386, 2006.

Lamy, F., Kilian, R., Arz, H. W., Francois, J., Kaiser, J., and Prange, M.: Holocene changes in the position and intensity of the southern westerly wind belt, Nat. Geosci., 3, 695-699, https://doi.org/10.1038/ngeo959, 2010.

Landschützer, P., Gruber, N., Haumann, F. A., Rödenbeck, C., Bakker, D. C. E., Heuven, S. Van, Hoppema, M., Metzl, N., 
Sweeney, C., and Takahashi, T.: The reinvigoration of the Southern Ocean carbon sink, Science, 349, 1221-1224, 2015.

Laskar, J., Robutel, P., Joutel, F., Gastineau, M., Correia, A. C. M., and Levrard, B.: A long-term numerical solution for the insolation quantities of the Earth, Astron. Astrophys., 428, 261-285, https://doi.org/10.1051/0004-6361:20041335, 2004.

Le Quéré, C., Rödenbeck, C., Buitenhuis, E. T., Conway, T. J., Langenfelds, R., Gomez, A., Labuschagne, C., Ramonet, M., Nakazawa, T., Metzl, N., Gillett, N. and Heimann, M.: Saturation of the Southern Ocean $\mathrm{CO}_{2}$ Sink Due to Recent Climate Change, Science, 316, 1735-1738, 2007.

Lister, D. and Jones, P.: Long-term temperature and precipitation records from the Falkland Islands, Int. J. Climatol., 35, 12241231, https://doi.org/10.1002/joc.4049, 2014.

Macphail, M. and Cantrill, D. J.: Age and implications of the Forest Bed, Falkland Islands, southwest Atlantic Ocean: evidence from fossil pollen and spores, Palaeogeogr. Palaeoclim. Palaeoecol., 240, 602-629, 2006.

Makou, M. C., Eglinton, T. I., Oppo, D. W., and Hughen, K. A.: Postglacial changes in El Niño and La Niña behavior, Geology, 38, 43-46, https://doi.org/10.1130/G30366.1, 2010.

Marshall, G. J.: Trends in the Southern Annular Mode from observations and reanalyses, J. Climate, 16, 4134-4143, https://doi.org/10.1175/15200442(2003)016<4134:TITSAM>2.0.CO;2, 2003.

Mayewski, P. A., Maasch, K. A., Dixon, D., Sneed, S. B., Oglesby, R., Korotkikh, E., Potocki, M., Grigholm, B., Kreutz, K., Kurbatov, A. V, Spaulding, N., Stager, J. C., Taylor, K. C., Steig, E. J., White, J., Bertler, N. A. N., and Jan, R.: West Antarctica's Sensitivity to Natural and Human-forced Climate Change Over the Holocene, J. Quaternary Sci., 28, 40-48, https://doi.org/10.1002/jqs.2593, 2013.

Mayewski, P. A., Carleton, A. M., Birkel, S. D., Dixon, D., Kurbatov, A. V., Korotkikh, E., Mcconnell, J., Curran, M., Cole-dai, J., Jiang, S., and Plummer, C.: Ice core and climate reanalysis analogs to predict Antarctic and Southern Hemisphere climate changes, Quaternary Sci. Rev., 155, 50-66, https://doi.org/10.1016/j.quascirev.2016.11.017, 2017.

Meehl, G. A., Arblaster, J. M., Bitz, C. M., Chung, C. T. Y., and Teng, H.: Antarctic sea-ice expansion between 2000 and 2014 driven by tropical Pacific decadal climate variability, Nat. Geosci., 9, 590-595, https://doi.org/10.1038/ngeo2751, 2016.

Mildenhall, D. C.: Exotic pollen rain on the Chatham Islands during the late pleistocene, New Zeal. J. Geol. Geophys., 19, 327-333, https://doi.org/10.1080/00288306.1976.10423562, 1976.

Moreno, P. I., François, J. P., Villa-Martinez, R. P., and Moy, C. M.: Millennial-scale variability in Southern Hemisphere westerly wind activity over the last 5000 years in SW Patagonia, Quaternary Sci. Rev., 28, 25-38, https://doi.org/10.1016/j.quascirev.2008.10.009, 2009.

Moreno, P. I., Villa-Martínez, R., Cárdenas, M. L., and Sagredo, E. A.: Deglacial changes of the southern margin of the southern westerly winds revealed by terrestrial records from SW Patagonia $\left(52^{\circ} \mathrm{S}\right)$, Quaternary Sci. Rev., 41, 1-21, https://doi.org/10.1016/j.quascirev.2012.02.002, 2012.

Orsi, A. H., Whitworth, T., and Nowlin, W. D.: On the meridional extent and fronts of the Antarctic Circumpolar Current, Deep. Res. Part I, 42, 641-673, https://doi.org/10.1016/09670637(95)00021-W, 1995.
Pike, J., Swann, G. E. A., Leng, M. J., and Snelling, A. M.: Glacial discharge along the west Antarctic Peninsula during the Holocene, Nat. Geosci., 6, 199-202, https://doi.org/10.1038/ngeo1703, 2013.

Power, M. J., Marlon, J., Ortiz, N., Bartlein, P. J., Harrison, S. P., Mayle, F. E., Ballouche, A., Bradshaw, R. H., Carcaillet, C., Cordova, C., and Mooney, S.: Changes in fire regimes since the Last Glacial Maximum: an assessment based on a global synthesis and analysis of charcoal data, Clim. Dynam., 30, 887-907, 2008.

Pritchard, H. D., Ligtenberg, S. R. M., Fricker, H. A., Vaughan, D. G., Broeke, M. R. Van Den, and Padman, L.: Antarctic ice-sheet loss driven by basal melting of ice shelves, Nature, 484, 502-505, https://doi.org/10.1038/nature10968, 2012.

Raphael, M. N., Marshall, G. J., Turner, J., Fogt, R. L., Schneider, D., Dixon, D. A., Hosking, J. S., Jones, J. M., and Hobbs, W. R.: THE AMUNDSEN SEA LOW: Variability, Change, and Impact on Antarctic Climate, B. Am. Meteorol. Soc., January, 1, 111122, https://doi.org/10.1175/BAMS-D-14-00018.1, 2016.

Rein, B., Lu, A., Reinhardt, L., Sirocko, F., Wolf, A., Dullo, W. C., Nin, E., Lückge, A., Reinhardt, L., Sirocko, F., Wolf, A., and Dullo, W. C.: El Niño variability off Peru during the last 20000 years, Paleoceanography, 20, 1-18, https://doi.org/10.1029/2004PA001099, 2005.

Roberts, D. E.: Quaternary history of the Falkland Islands (Doctoral dissertation, University of Aberdeen), 1984.

Russell, A. and McGregor, G. R.: Southern hemisphere atmospheric circulation: Impacts on Antarctic climate and reconstructions from Antarctic ice core data, Clim. Change, 99, 155-192, https://doi.org/10.1007/s10584-009-9673-4, 2010.

Schneider, D. P., Deser, C., and Okumura, Y.: An assessment and interpretation of the observed warming of West Antarctica in the austral spring, Clim. Dynam., 38, 323-347, https://doi.org/10.1007/s00382-010-0985-x, 2012.

Sime, L. C., Kohfeld, K. E., Le, C., Wolff, E. W., Boer, A. M. De, Graham, R. M., and Bopp, L.: Southern Hemisphere westerly wind changes during the Last Glacial Maximum: model-data comparison, Quaternary Sci. Rev., 64, 104-120, https://doi.org/10.1016/j.quascirev.2012.12.008, 2010.

Stockmarr, J. A.: Tabletes with spores used in absolute pollen analysis, Pollen spores, 13, 615-621, 1971.

Thomas, Z., Turney, C., Allan, R., Colwell, S., Kelly, G., Lister, D., Jones, P., Beswick, M., Alexander, L., Lippmann, T., Herold, N., and Jones, R.: A new daily observational record from Grytviken, South Georgia: exploring 20th century extremes in the South Atlantic, J. Climate, 31, 1743-1755, https://doi.org/10.1175/JCLID-17-0353.1, 2018.

Thomas, Z. A.: Using natural archives to detect climate and environmental tipping points in the Earth System, Quaternary Sci. Rev., 152, 60-71, https://doi.org/10.1016/j.quascirev.2016.09.026, 2016.

Thompson, D. W. J., Solomon, S., Kushner, P. J., England, M. H., Grise, K. M., and Karoly, D. J.: Signatures of the Antarctic ozone hole in Southern Hemisphere surface climate change, Nat Geosci., 4, 741-749, https://doi.org/10.1038/ngeo1296, 2011.

Turner, J., Phillips, T., Hosking, J. S., Marshall, G. J., and Orr, A.: The Amundsen Sea low, Int. J. Bifurcat. Chaos, 1829, 18181829, https://doi.org/10.1002/joc.3558, 2013.

Turner, J., Lu, H., White, I., King, J. C., Phillips, T., Hosking, J. S., Bracegirdle, T. J., Marshall, G. J., Mulvaney, R., and 
Deb, P.: Absence of 21st century warming on Antarctic Peninsula consistent with natural variability, Nature, 535, 411-415, https://doi.org/10.1038/nature18645, 2016.

Turney, C. S. M., Jones, R. T., Fogwill, C., Hatton, J., Williams, A. N., Hogg, A., Thomas, Z. A., Palmer, J., Mooney, S., and Reimer, R. W.: A 250-year periodicity in Southern Hemisphere westerly winds over the last 2600 years, Clim. Past, 12, 189-200, https://doi.org/10.5194/cp-12-189-2016, 2016a.

Turney, C. S. M., Jones, R. T., Lister, D., Jones, P., Williams, A. N., Hogg, A., Thomas, Z. A., Compo, G. P., Yin, X., Fogwill, C. J., Palmer, J., Colwell, S., Allan, R., and Visbeck, M.: Anomalous mid-twentieth century atmospheric circulation change over the South Atlantic compared to the last 6000 years, Environ. Res. Lett., 11, 064009, https://doi.org/10.1088/17489326/11/6/064009, 2016b.

Turney, C. S. M., Fogwill, C. J., Palmer, J. G., van Sebille, E., Thomas, Z., McGlone, M., Richardson, S., Wilmshurst, J. M., Fenwick, P., Zunz, V., Goosse, H., Wilson, K.-J., Carter, L., Lipson, M., Jones, R. T., Harsch, M., Clark, G., Marzinelli, E., Rogers, T., Rainsley, E., Ciasto, L., Waterman, S., Thomas, E. R., and Visbeck, M.: Tropical forcing of increased Southern Ocean climate variability revealed by a 140 -year subantarctic temperature reconstruction, Clim. Past, 13, 231-248, https://doi.org/10.5194/cp-13-231-2017, 2017a.

Turney, C. S. M., Wilmshurst, J. M., Jones, R. T., Wood, J. R., Palmer, J. G., Hogg, A. G., Fenwick, P., Crowley, S. F., Privat, K., and Thomas, Z.: Reconstructing atmospheric circulation over southern New Zealand: Establishment of modern westerly air flow 5500 years ago and implications for Southern Hemisphere Holocene climate change, Quaternary Sci. Rev., 159, 7787, https://doi.org/10.1016/j.quascirev.2016.12.017, 2017b.
Upson, R., Williams, J. J., Wilkinson, T. P., Clubbe, C. P., Ilya, M., Maclean, D., Mcadam, J. H., and Moat, J. F.: Potential Impacts of Climate Change on Native Plant Distributions in the Falkland Islands, PLoS One, 11, e0167026, https://doi.org/10.1371/journal.pone.0167026, 2016.

van Oldenborgh, G. J. and Burgers, G.: Searching for decadal variations in ENSO precipitation teleconnections, Geophys. Res. Lett., 32, 1-5, https://doi.org/10.1029/2005GL023110, 2005.

Villa-Martínez, R., Moreno, P. I., and Valenzuela, M. A.: Deglacial and postglacial vegetation changes on the eastern slopes of the central Patagonian Andes (47 ${ }^{\circ} \mathrm{S}$ ), Quaternary Sci. Rev., 32, 8699, https://doi.org/10.1016/j.quascirev.2011.11.008, 2012.

Visbeck, M.: A station-based southern annular mode index from 1884 to 2005, J. Climate, 22, 940-950, https://doi.org/10.1175/2008JCLI2260.1, 2009.

Wace, N. and Dickson, J.: Part II. The terrestrial botany of the Tristan da Cunha Islands, Philos. T. R. Soc. B, 249, 273-360, https://doi.org/10.1098/rstb.1965.0014, 1965.

Wessel, P., Smith, W. H. F., Scharroo, R., Luis, J., and Wobbe, F.: Generic Mapping Tools: Improved Version Released, Eos, Trans. Am. Geophys. Union, 94, 409-410, https://doi.org/10.1002/2013EO450001, 2013.

Whitlock, C., Larsen, C., Smol, J. P., Birks, H. J. B., and Last, W. M.: Tracking environmental change using lake sediments, Track. Environ. Change Using Lake Sed., 3, 75-97, 2001.

Wilson, P., Clark, R., Birnie, J., and Moore, D. M.: Late Pleistocene and Holocene landscape evolution and environmental change in the Lake Sulivan area, Falkland Islands, South Atlantic, Quaternary Sci. Rev., 21, 1821-1840, https://doi.org/10.1016/S02773791(02)00008-2, 2002. 